\title{
Uncovering the pedagogical potential of texts : Curriculum materials in classroom interaction in first language and literature education
}

\section{Karvonen, Ulla}

2018-06

Karvonen , U , Tainio , L \& Routarinne , S 2018 , ' Uncovering the pedagogical potential of texts : Curriculum materials in classroom interaction in first language and literature education

' , Learning, Culture and Social Interaction , vol. 17 , pp. 38-55 . https://doi.org/10.1016/j.lcsi.2017.12.003

http://hdl.handle.net/10138/313179

https://doi.org/10.1016/j.lcsi.2017.12.003

submittedVersion

Downloaded from Helda, University of Helsinki institutional repository.

This is an electronic reprint of the original article.

This reprint may differ from the original in pagination and typographic detail.

Please cite the original version. 


\title{
Uncovering the pedagogical potential of texts: Curriculum materials in classroom interaction in first language and literature education
}

\begin{abstract}
Most teachers in many Western countries make use curriculum materials such as textbooks, workbooks and related teacher's guides in their teaching. In this study, 29 First language and literature lessons are analysed to discover different ways in which texts that are part of curriculum materials are used in the curriculum. The findings indicate that the identification of the pedagogical potential of the texts demands a profound understanding of the subject matter. Moreover, the realization of this potential always involves creativity and improvisation. Thus, we suggest that preparedness to read curriculum materials analytically and critically is a core component of teachers' expertise.
\end{abstract}

Keywords: First language and literature education; literacy; curriculum materials; curriculum enactment; classroom interaction; conversation analysis

\section{Introduction}

Elementary and lower-secondary school teachers in Finland and Western countries in general report that they frequently use ready-made curriculum materials such as textbooks, workbooks, and teachers' guides in their teaching (e.g., PIRLS, 2011; TIMSS, 2011). Among scholars, however, attitudes towards the use of curriculum materials differ considerably. Critics of curriculum materials claim that ready-made instructional materials fundamentally reduce teachers' professional autonomy by obliging them to follow closely the sequence of topics and activities offered by the materials (e.g., Apple, 1986, 85-86; Koutselini, 2012). Some of the critics even maintain that textbooks are designed to "transmit hard-and-fast unambiguous knowledge in the least problematic 
manner possible" (Benhur Oral, 2013, 319), and they cannot be used for any other purposes. Thus, the critics argue, professional teachers should be able to create their curriculum without relying on externally produced curriculum materials (Luke, 1988).

Advocates of the use of ready-made curriculum materials, on the other hand, suggest that while the existing materials have their shortcomings, they still support teachers in developing their practice and their knowledge about teaching and novice teachers can find them especially helpful (e.g., Ball \& Feiman-Nemser, 1988; Grossman \& Thompson, 2008). Notably, in the fields of mathematics and science education, the development of curriculum materials that are designed to support teacher learning is seen as an effective way of promoting teacher learning and improving teaching (e.g., Ball \& Cohen, 1996; Davis \& Krajcik, 2005; Drake, Land \& Tyminski, 2015).

The findings of empirical studies on teachers' use of curriculum materials highlight teachers' agency in relation to curriculum materials. Several studies (e.g., Collopy, 2003; Remillard, 1999; Sherin \& Drake, 2004; Thompson \& Senk, 2014) have pointed out that teachers tend to use the materials selectively and modify the suggested activities to suit their own purposes, needs and interests. In fact, curriculum materials cannot determine the subject matter or how it is taught because teachers' knowledge, capacities, beliefs, values and experiences influence how they perceive, interpret and utilise the materials (e.g., Remillard, 2005). Hill and Charalambous (2012) analysed two teachers' enactment of a mathematical task provided by the curriculum materials. Their study demonstrates that teachers' task enactment depends on his or her understanding of the content (Hill \& Charalambous, 2012; see also, Remillard, 1999). In summary, previous research shows that although curriculum materials influence learning opportunities encountered by the students, the teacher always mediates their influence. Therefore, the capacity to use curriculum materials in ways that promote student learning is among the core components of teachers' expertise (e.g., Ben-Peretz, 1990; Schwartz et al., 2008; Taylor, 2013). 
The findings of our recent review (Karvonen, Tainio \& Routarinne, forthcoming) indicate that the field of research on curriculum materials in Finnish basic education is unilaterally dominated by textbook analyses examining the content of students' materials with the aim of determining how they shape classroom activities and student learning. Furthermore, elsewhere it has been suggested that researchers tend to find it tempting to make inferences about what really happens in classrooms based on curriculum materials alone (Love \& Pimm, 1996). In this article, we take another approach. Following some earlier studies (e.g., Karvonen, Tainio, Routarinne \& Slotte, 2015; Pitkänen-Huhta, 2003; Sunderland, Rahim, Leontzakou \& Shattuck, 2001), we argue that the teacher has a powerful role as the mediator between curriculum materials and classroom activities. Thus, we regard it as important to complement textbook analyses with studies examining the situated use of curriculum materials in the actual contexts in which they are deployed, that is, as central elements of classroom ecology (e.g., Guerrettaz \& Johnson, 2013). A more profound understanding of how curriculum materials are deployed in and for teaching in classrooms enables researchers to discover what knowledge and skills the effective use of curriculum materials demands (e.g., Ball, Thames \& Phelps, 2008). Thus, it helps to develop teacher education programmes that provide prospective teachers with opportunities to learn to better use different curriculum materials for promoting student learning. Moreover, it helps the authors of the curriculum materials to design materials that serve the teachers' needs.

The aim of this article is to describe teachers' curriculum use in naturally occurring classroom interaction during first language and literature lessons ${ }^{1}$ in Finnish basic education. Like Ben-Peretz $(1990,2010)$ and Remillard (2005), we use the term 'curriculum use' to refer to the ways in which teachers draw on and employ various kinds of printed and electronic materials. In this study, the focus is on printed curriculum materials designed for use by students and teachers in classrooms. More specifically, the term curriculum materials is used in this article to refer to students' textbooks

\footnotetext{
${ }^{1}$ In Finnish basic education, over $90 \%$ of students study Finnish as the first language.
} 
and workbooks and related teachers' guides. We limit our study to these resources as Finnish teachers have reported in various surveys that these are the most commonly used curriculum materials in many academic school subjects, including first language and literature education (e.g., Atjonen et al., 2008, 124; PIRLS, 2011; Tainio, Karvonen \& Routarinne, 2015).

\section{Curriculum materials as pedagogical resources}

Teachers are shown to utilise curriculum materials at different phases of teaching: in planning the lessons, during instruction and in evaluating the lessons afterwards (e.g., Remillard, 1999; Sharin \& Drake, 2009). In this article, we examine teachers' curriculum use in the context of an enacted curriculum. Enacted curriculum refers to an emergent trajectory of interaction between teachers and students during and across the lessons (e.g., Remillard \& Heck, 2014; Snyder, Bolin \& Zumwalt, 1992). In transforming the official curriculum into lesson plans, teachers often draw on both curriculum materials and their own knowledge, including their professional knowledge (e.g. Stein, Remillard \& Smith, 2007). Whether detailed scripts or broad-minded sketches, teachers' and curriculum designers' pre-arranged ideas about the course of activities cannot be implemented as such because the actual lesson unfolds in turn-by-turn interaction among the participants (e.g. Remillard \& Heck, 2014). In other words, enacted curriculum is contingent on participants' responses to each other's actions; therefore, teaching always requires creativity and improvisation (Sawyer, 2004). This kind of approach to curriculum use emphasises the co-constructed nature of classroom discourse. Thus, it helps to understand the complex relationship between curriculum materials and classroom practices.

While curriculum materials may influence an enacted curriculum in many ways, the focus of this study is on the instances in which the texts embodied by curriculum materials are observably integral to participants' interactions. These episodes are referred to as literacy events (e.g., Barton, 2007; Pitkänen-Huhta, 2003). Participants of the literacy event may treat different kinds of texts as 
a shared reference point. ${ }^{2}$ Many of these texts invite readers to act on them, with the aim of engaging the students in different literacy practices. Therefore, manipulations made by the students, such as written answers in fill-in-the-blank exercises, are often treated as part of the text that is brought into the focus of joint attention during literacy events.

As tool kits designed for supporting the achievement of particular curricular goals, curriculum materials carry their developers' intentions and make those intentions available for the readers through explicit instructions, headings, captions and layout (Brown, 2009; Wells, 1999). Moreover, the teachers' guide may advise the teacher to emphasise some of the ideas and concepts and suggest classroom activities related to the texts. Each text is designed for specific purposes; therefore, it embodies certain intended affordances that enable a certain set of activities (Guerrattaz \& Johnson, 2013). However, all texts embody a rich array of pedagogical potential, that is, a range of possible ways of using the text for various pedagogical purposes that may not have even been imagined by the designers (e.g., Ben-Peretz, 1990; Brown, 2009). In first language and literature education, in particular, a single text can be made use of as a starting point for various tasks that enable practising different skills in the framework of linguistics and literature studies (e.g., Tainio \& Grunthal, 2016). In realizing the pedagogical potential of the text in classroom, the teacher may attempt to conduct activities in accordance with the guidelines provided by the authors. Alternatively, s/he may draw on her or his knowledge to discover other possible ways of using the text. In Finland, teachers have autonomy to choose the materials and methods they use in teaching. Moreover, authors typically provide only loose guidelines with curriculum materials. Thus, teachers need to rely on their own knowledge even when attempting to follow the official curriculum and provided guidelines.

\footnotetext{
${ }^{2}$ In Finland, first language and literature education is based on a broad conception of texts. Curriculum materials contain a wide variety of different types of texts: fictive, factual, verbal, figurative and graphic. Thus, textbooks and workbooks can be characterized as a macrogenre (Martin \& Rose, 2008).
} 
From the 1980s, researchers have attempted to determine the distinctive body of knowledge that teachers need to function successfully in their profession (e.g., Shulman, 1987; Verloop, van Drier \& Meijer, 2001). In this study, we adopt a practice-based view on this knowledge base for teaching (e.g., Ball \& Forzani, 2009; Grossman \& McDonald, 2008). According to this view, research on teachers' knowledge base should begin by identifying the core practices of teaching and then infer knowledge and skills that permit teachers to perform them (e.g., Ball, Thames and Phelps, 2008). Our study contributes to this body of research by analysing curriculum use in first language and literature classrooms. The purpose of the study is to describe different ways in which teachers realise the pedagogical potential of texts in enacting the curriculum. We analyse literacy events emerging in naturally occurring classroom interaction to answer the following questions:

1. How do teachers use texts provided by curriculum materials in the enacted curriculum?

2. How is the pedagogical potential of the text realized through teachers' verbal and embodied practices?

3. How is teachers' knowledge base manifested in the way they use the texts during the literacy event?

\section{Data and methods}

The data for this study comprise naturally occurring classroom interaction in Finnish comprehensive schools with students on grade 6 (aged 12 years). Video recordings consist of altogether 29 first language and literature lessons, each lasting for 45 minutes. The topics of lessons mirror the wide spectrum of content areas of language and literature education: literature, film, drama, student writing and language awareness, including grammar. All teachers and students as well as students' guardians gave an informed consent for collecting video data and using it for research purposes. All excerpts are anonymized to maintain confidentiality. 
The data was collected over many years, from 2004-2012 for different research projects in urban public schools located in Southern Finland. By and large, these schools can be characterised as typical Finnish elementary schools in that the students are mainly children who live nearby the school and they come from diverse social and cultural backgrounds. About two-thirds of the schools were randomly selected and in the remainder, a convenience sampling technique was applied to reach the participants. The data offers frequent literacy events during which the participants work on texts provided by textbooks and workbooks, and thus it is possible to identify representative examples of teacher's use of curriculum materials that are useful for understanding of teachers' curriculum use even more generally.

Multimodal conversation analysis (CA) was used to analyse the data. We selected CA because it offers tools for detailed examination of participants' verbal and embodied practices as well as material artefacts they use in co-constructing the enacted curriculum. Conversation analysts examine naturally occurring interaction to determine how participants use a range of interactional practices to accomplish different social actions and achieve and maintain shared understanding (e.g., Sidnell \& Stivers (Ed.), 2013; Streeck, Goodwin \& LeBaron, 2011). In classroom settings, conversation analysts have examined specific practices used by teachers and students with the aim of accomplishing the institutional tasks of schooling, that is, teaching and learning (e.g., McHoul, 1978; Kääntä, 2010; Majlesi \& Broth, 2012). Among conversation analysts there has recently been an increased interest in the use of learning materials in educational settings (e.g., Jakonen 2015; in press; Kunitz, 2015; Majlesi, 2014).

For the purposes of this study, all video data was transcribed by adopting the conventions of conversation analysis (e.g., Hepburn \& Bolden, 2013). We also transcribed embodied practices such as gaze and gestures as far as they were observably oriented by the participants as relevant for the ongoing activities. In transcribing embodied conduct, we used transcription symbols developed by Mondada (2007). CA transcripts are highly detailed and can provide the reader with an opportunity 
to confirm or challenge interpretations made by the researcher(s). In the excerpts presented in this article, we have simplified the transcripts and omitted details that are not necessary for our analysis. The transcription conventions can be found in the Appendix. The curriculum materials used during the literacy events were examined to disclose their manifested pedagogical potential and determine ways in which the participants drew on them. Excerpts of texts used during the analysed episodes are also shown.

In our analysis, we focused on whole-class interaction. We identified altogether 60 literacy events during which participants acted on or talked about texts provided by curriculum materials. We paid special attention to teachers' turns-of-talk that focused joint attention onsome aspects, features or elements of the text. All these turns-of-talk were closely analysed to identify verbal and embodied practices used by the teachers. We learned that teachers used both verbal means, such as inquiring and requesting and embodied practices, such as gazing and pointing as methods for creating a shared understanding about the object of the ongoing activity.

Next, we focused more carefully on the verbal content of teachers' turns to determine how they guided the students to read the text. We found out that teachers' questions and requests required students to adopt different approaches to the text: students were expected to repeat or rephrase a certain word or fragment of the text to explain the meaning of a word, fragment, or a visual feature of the text, or to analyse pieces of text in order to identify particular morphological or syntactic elements. In addition to initiatives such as questions and requests, teachers specified and clarified what they thought was relevant for the students to see or understand when working on the text.

In accordance with the methodology of conversation analysis, the validity of our interpretations was secured by relying on so-called next-turn proof procedure: in producing a turn-of-talk, the current speaker displays her or his understanding of what the previous speaker meant to be doing by his or her turn (e.g., Peräkylä, 2004). Unless the interpretation made by the current speaker is not treated as incorrect by some other participant, we as analysts can treat it as a sufficient interpretation. If the 
teacher produced a turn-of-talk that is linguistically formatted as an interrogative, the student responded by reading aloud a word from the textbook and the teacher provided a positive evaluation, we inferred that the question was designed to guide the students to look for a particular passage or word that could be rephrased or repeated as an answer. If the teacher did not accept the answer provided by the student but rephrased the question or asked the student to elaborate his or her answer or if s/he further elaborated or defined the answer provided by the student, we concluded that the understanding of the text displayed by the student answer was either incorrect or did not shed light on all those aspects or features of the text that the teacher intended the students to notice. In these cases, we examined how the sequence continued to discover how a shared understanding of the text was accomplished. Moreover, the authors discussed the data excerpts in joint data sessions to secure the reliability of interpretations.

Finally, we examined the texts used during literacy events closely to determine in which teaching practices and learning activities teachers and students are presumed to enact and participate. Authors of the curriculum materials can make their ideas concerning the use of texts available for the users of the materials through explicit guidelines and visual features. We analysed explicit instructions for using the texts that were provided by students' materials and teachers' guidebooks in order to identify the intended pedagogical potential of the texts. Moreover, we paid attention to those graphical features that highlighted some aspect of the text even though they were not explicitly mentioned in the instructions. To determine the degree to which the teachers relied on their personal or professional knowledge in enacting the curriculum, the actual uses of texts were compared to their intended affordances manifested in curriculum materials, especially in teachers' guides. 


\section{Findings}

During literacy events, the realization of pedagogical potential of a text was accomplished in and through such practices as formulating problems, inquiring, responding to students' ideas and providing explanations. In enacting these practices, teachers brought particular aspects of texts into the focus of joint attention as relevant objects of learning and, simultaneously, confirmed or dismissed understandings of texts expressed by the students. Next, we present the analysis of data excerpts that illustrate the diversity of ways in which teachers draw on curriculum materials in enacting the curriculum.

\subsection{Using the text as a source of authoritative knowledge}

Textbooks are often claimed to have authority in the classrooms and the source of their power is said to lie at least partly in the way in which they are used in classrooms (e.g., Baker \& Freebody, 1989; Pinto, McDonald \& Boyd, 2011; Tainio, forthcoming). Next, we will analyse an episode during which the teacher approaches the textbook text as a source of authoritative knowledge and invites the students to reproduce the information provided by the text. This kind of approach to a text has been referred to as a dominated approach (Apple \& Christian-Smith, 1991); it has been found to be common among the teachers (e.g., Pinto, McDonough \& Boyd, 2011); however, it was rare in our Finnish data.

The topic of the lesson is cinema; before the beginning of this excerpt, the teacher has introduced a new topic: the structure of films. After asking the students to recall what they remember about the structure of narrative school composition, ${ }^{3}$ she draws a parallel between the structure of a film and the composition: in both there is a starting point, a problem, attempts to solve the problem and an ending. Then, she informs the students that the structure of film will be discussed in terms of a

\footnotetext{
${ }^{3}$ In this case, the school composition refers to a narrative text written by the students. In elementary school in first language and literature education, these kinds of narrative texts are very common.
} 
model provided by the textbook, asks the students to take out their textbooks and announces the textbook page. On the textbook page, the text is presented without any explicit guidelines for how it could be used. The text portrays the structure of film as six consecutive phases. The distinctiveness of the phases is highlighted by their presentation in separate boxes and the linear nature of the storyline is e mphasized by illustrating the relationship between successive phases with arrows (see Figure 1).

Figure 1. Basic structure of a film (Source: Salainen Kerho, basic book, pp. 151)

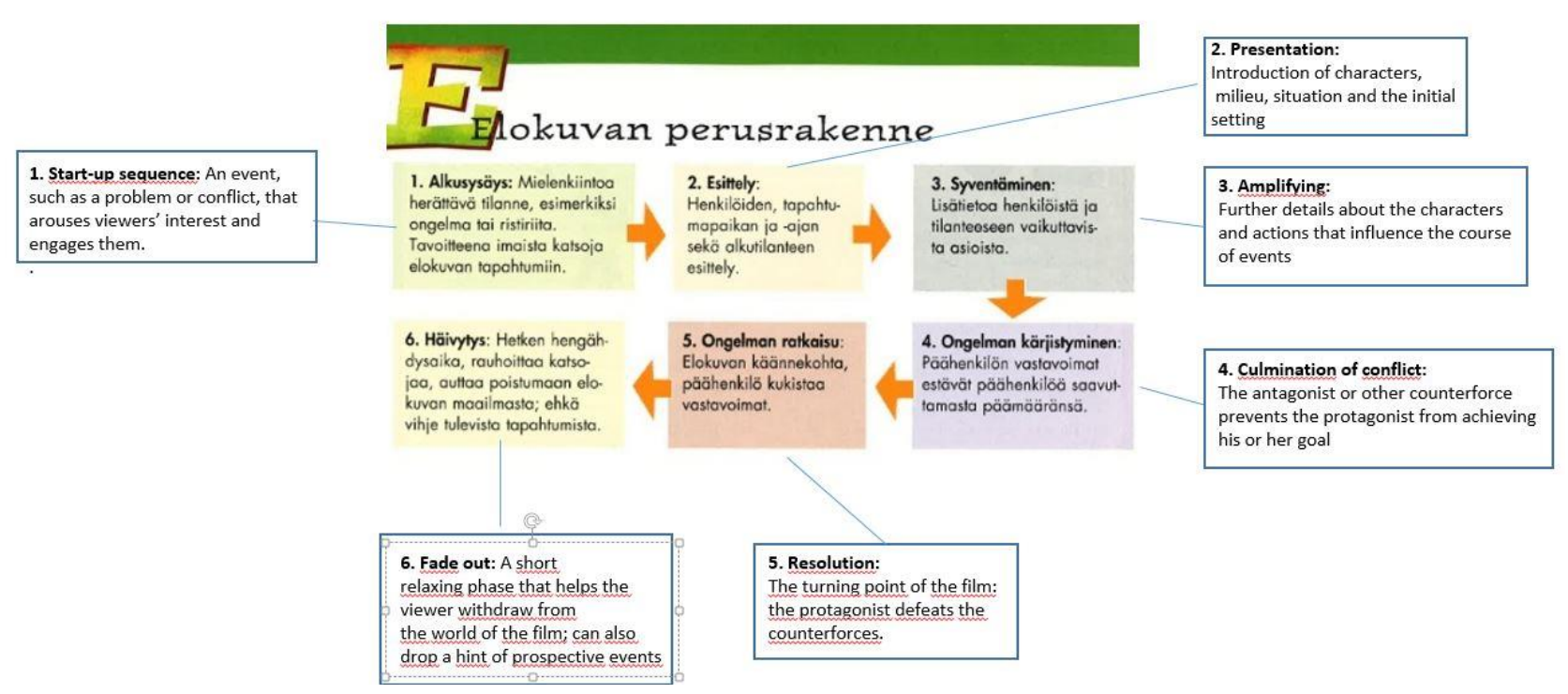

In the transcript, embodied actions are represented on separate lines below the lines representing speech. At the beginning of each line, the participant is identified by his or her pseudonym. Tch refers to teacher. Under the lines representing talk, relevant embodied actions of the participants are marked: $G$ signifies gaze, $H a$ refers to hand movements and $H e$ to head movements. Utterances in quotation marks are read aloud from the textbook or workbook.

Extract 1 . The film, excerpt 1a.

1. Tch: *nyt (.) tämmönen (0.5)*mistä *elokuva sitten alkaa *now (.) this kind $(0.5) *$ where $*$ does the film start.

TchG *students *book *students

3. Tch: mikä ois (se mikä elokuvissa) *(.)* ihan perustana: on tän (.) 

$T \operatorname{ch} G$ :
what would it be that in films * (.) *is the very basis (.)
*book * students

4. tämän *(.)*tutkijam mukaa joka on joka *^teidän *kirjanneki on

this *(.)* according this researcher who has who* ${ }^{*}$ authored your

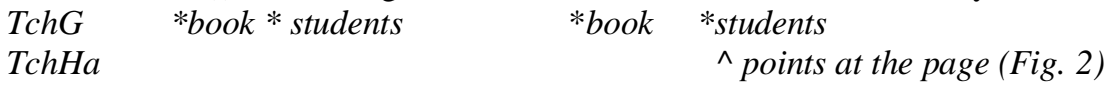

5. tehny.=tässä $*$ on ihan selkeä*

textbook=here $*$ is a very clear-cut $*$

TchG *book *students

5.

6. Tch: kuvaus elokuvan *kulusta. *

description of the course of a film

TchG: *book *students

7. (1.4)

8. Tch: *mikä on *ensimmäinen.

* what is *the first

TchG: *book *students

9. (5.8) ((students are silent and most of them appear to look at the text))

10. Tch: $\% *$ katsokaa siitä \&sivulta (.)*sataviiskymmentyks.

$\% *$ look there $\&$ at the page (.) *one hundred and fifty-one *

TchG: *book *the floor *students

TomiHa: \%raises his hand

TomiG: \&teacher

11. (6.3) ((the teacher looks around the classroom))

12. Tch: miettikää yhdessä jos ei yksin ke- keksi. (.) \&miettikää yhdessä.

TomiG: consider it together if you can't make it alone (.) \& consider it together

13. (1.0)

14. Tch: $\%$ keskustelkaa keskenänne.

$\%$ discuss together

TomHa: \% hand down

During the whole episode, the teacher stands in front of the students and holds the teachers' guide in her hand. The students have their textbooks open on the desk. At the beginning of the excerpt, the teacher initiates discussion on the structure of films by asking a question concerning the beginning of the film (line 1). During the whole episode, the teacher then recycles the same inquiry. These elicits are formatted either as questions (lines 1, 3 and 8) or as directives (lines 10, 12 and 14). Despite her continuous efforts, the students remain silent. Most of the time, they stare at their 
textbooks as if to avoid the teacher's gaze; thus, they observably display unwillingness to respond (e.g., Sert, 2011). To be sure, after the teacher's second prompt (1. 8), Tomi raises his hand and turns to look at the teacher (1. 10), presumably to volunteer to answer. The teacher, however, does not appear to notice him.

Throughout the episode, the teacher invites the students to consult their textbooks as the source of information for providing an answer. First, she uses the indexical pronoun tässä (here) accompanied by pointing with her finger at a particular spot on a page in the teacher's guide she handles in order to locate the information sought out more exactly (1. 4). The students, however, do not have visual access to that page, so they have to infer the exact target of pointing. After a gap (1.5) the teacher specifies the target verbally, defining it as "a clear-cut description of the course of a film" (1. 6). A bit later, she asks about "the first one", apparently referring to the numbered parts of a film as introduced in the text; thus, she further stresses the role of the text as a source of knowledge (1. 8). Moreover, she emphasizes the trustworthiness of the information provided by the textbook by referring to the author of the text as a researcher (1. 4). As the students remain silent, she invites them again to consult the textbook and repeats the correct page number (1. 10). Then, she tells them to consider the answer together (1. 12) and discuss it (1. 14) but with no result. The next excerpt begins after the silence that follows the teacher's last prompt.

Extract 1. The film, excerpt $1 b$.

15.

16. Tch: mistä elokuva usein (alkaa). where does the film often begin.

17. $\quad(5.0) \&(1.0)$

MiikaG: \& teacher

18. Miika: musiikilla. with music

19. (1.0)

20. Tch: \#musii\#kil\%la?\% \& \#with \#music?

TchG \#Miika\#students 
MiikaHa:

MiikaG: \%hand up index raised \%hand down

\&textbook

21. Niko: vääri.

incorrect

22. Tch: ja niillä (.) kuvateksteillä. (.) missä (ne esiintyjät) kyllä? \$

TchHe: and those (.) subtitles (.) in which (the performers) yes? \$

23.

24. Tch: musiikki on varmasti semmonen (.) hyvin tärkee ja siihen palataanki kohta eli mietitään the music is certainly a kind of (.) very important and we'll come back to it later or we'll consider

25 . vähän, (.) elokuvamusiikkia mut että? .hh mikä on niinkun tämän (.) tämän ää (.) a little bit (.) of film music but then? .hh what is the first part of this (.) of this uhm (.)

26. varsinaisen elokuvan. (.) ensimmäinen osa of the actual film

After the teacher has repeated the inquiry for the fourth time (1. 16), Miika self-selects himself and proposes music as an answer (1. 18). Instead of consulting the textbook as the teacher has advised, he appears to rely on his own experiences as a viewer of films. A silence after Miika's suggestion (1. 19) indicates that the answer was not the one the teacher expected. Finally, she repeats his answer with rising intonation (1.20) and Niko, quite correctly, interprets this to mean that the teacher treats the answer as problematic, or, as he formulates it, väärin (incorrect) (1. 21). Simultaneously, the teacher shifts her gaze from Miika to other students as if to look for the next respondent.

Because the answer implied a misunderstanding or misconception on the part of the student, the teacher is confronted with a demand to define more precisely what she —or the text—means when referring to an initial phase of a film. The teacher does not reject Miika's response as incorrect but she does not treat it as completely correct either. Instead, she acknowledges that music really occurs in the beginning of films but equates it with the subtitles (she probably means the opening credits) rather than the actual film (1. 22). After a silence (1. 23), she topicalizes the role of music, accepts it as an essential element of the films and projects the course of the lesson by noting that the music will be discussed later at some length (1. 24-25). Then she rephrases the question, emphasizing that they are searching for the first phase of the actual film (1. 25-26). By using a contrasting 
conjunction mut (but), she distinguishes between the actual film and the actions happening before or parallel to it but does not further elaborate on the differences between the two. The last excerpt begins with a silence that follows the teacher's question (1. 27).

Extract 1. The film, excerpt 1c.

27.

28. Tch: mitä tarvitaan jotta lukija pääsee \&\% jyvälle mistä on kysymys. what do we need so that the reader can figure out what it is about

IirisG: IirisH:

$$
\begin{aligned}
& \text { \& Ronja } \\
& \text { \%points at Ronja's book }
\end{aligned}
$$

29. (1.0) ((Iiris turns back to her own desk))

30. Tch: Iiris a kerro \& sinä.

Iiris you tell.

IirisG: \&teacher

MiikaG: $\quad$ atiris

31.

IirisG:

(0.4) \& (1.0)

$$
\text { \&book }
$$

32. Tch: mikä siellä on ensimmäisenä.

what is there as the first thing

33. Iiris: emmä tiiä \& \#

I don't know

$\begin{array}{cc}\text { IirisG: } & \text { \&teacher } \\ \text { TchG: } & \text { \#book }\end{array}$

34. Miika: $\uparrow$ mitä? (.) [£et tiiä (.) (kato sitä kuvaa)£]

$\uparrow$ what? (.) [£you don’t know (.) (look at the picture)£]

35. Tch: ["elokuvan \#perusrakenne"=\#mistä elokuva alkaa.]

["the basic structure of a film"\# where does a film begin]

$T \operatorname{ch} G:$

$$
\text { \# Iiris \#right side of classroom }
$$

36. \#(3.0) \# (2.0) \# (1.0)

TchG: \#Iiris \#right side of the classroom \#textbook

37. Iiris: “alku\#sysäys.”\#

"a stimulus"\#

TchG: $\quad$ \#Iiris $\quad$ \#book

38.

39. Tch: \#"alkusysäys". \# (2.0) \# se on nyt ihan samalla tavalla ku meidän kirjotelmissa on se alkutilanne. (.)

\# "a stimulus." \# (2.0) \#so now this is exactly like the initial situation in our stories (.)

TchG: \#students \#book \#students

40. eli? (.) kuvataan, (1.0) jotakin (1.5) annetaan semmosta perustietoa katsojalle.

so? (.) something (1.0) is described (1.5) some basic information is given to the viewer. 
As the teacher is rephrasing the question (1. 28), Iiris, who has been leafing through her textbook already for some time, turns to Ronja, who sits next to her and points with her finger to something in Ronja's textbook. Apparently due to the divergent behaviour displayed by Iiris, the teacher nominates her and asks her to answer the question (1. 30). Iiris turns to look at the teacher (1. 30) and then returns to the text, as if to consult it to find the answer (1.31). The teacher continues to look at her and reformulates the question as such that it can be understood to refer to the first item of the model (1. 32, see also Figure 1). Instead of answering, Iiris accounts for not answering by pleading that she does not know the answer (1. 33). Miika, who sits opposite to Iiris, has been looking at her smiling since the teacher has addressed her (1.30). He produces an open class repair initiator mitä (what); thus, he treats Iiris' previous turn as somehow problematic (Drew, 1997; Haakana, 2011). By repeating the account provided by Iiris, he indicates that the trouble does not arise from problems in hearing. Moreover, both his facial expression and prosodic features of the turn exhibit astonishment (Selting, 1996). Then, he advises Iiris to look at the text (1. 34).

The teacher ignores Miika's comment and rephrases the question after reading aloud the title of the textbook page (1. 35). During the following silence, the teacher first looks at Iiris as if still waiting for her to answer but then turns to look at the other students and finally at the textbook (1. 36). After the teacher has already turned to her textbook, Iiris reads aloud the title of the first box (1. 37). The teacher looks at the textbook, apparently checking for the correct word (1. 38). Then she repeats the answer, draws an analogy between the stimulus mentioned in the textbook and the initial situation of the school composition, and paraphrases the main features of the stimulus (1. 39-40).

In this example, the teacher approaches the text as an authoritative source of knowledge and prompts the students to reproduce the content of the text verbatim. From the very beginning of the event, the teacher is clear that she expects the students to answer her questions by using their textbooks, rather than relying on their own observations or experiences as viewers of films. Students' evident unwillingness to participate in the discussion may arise from the lack of interest 
or motivation to answer inquiries that require them to merely read aloud passages from the textbook but both Miika's incorrect response (1. 18) and a claim of insufficient knowledge by Iiris (1. 33) indicate that, despite the repeated references to the text and requests to consult it, the teacher has not succeeded in creating a common point of reference.

Throughout the event, the teacher formulates questions that can be answered by reading aloud a word from the textbook and displaying and reproducing the authority of the text (e.g., Baker \& Freebody, 1989; Pinto, McDonough \& Boyd, 2011). The textbook does not provide any information about the purpose and potential uses of the model and the teacher fails to rely on her own background knowledge or knowledge provided by the materials to complement this shortcoming. In the teacher's guide, the text is introduced as a general model that suits the analysis of many schematic movies; however, the teacher presents it as a generalizable account that applies across different modalities. Therefore, she fails to emphasize the nature of the model as a simplified version of the phenomena and does not bring out its affordances, strengths and limitations. In fact, in drawing an analogy between the structure of a film and a structure of a school composition, she may even hint that the model should be understood as a normative description of a good film.

\subsection{Highlighting the object of learning}

Language awareness is one of the sub-areas of first language and literature education in Finnish basic education. In our survey, class teachers reported that they use curriculum materials most frequently in teaching grammar (Tainio, Karvonen \& Routarinne, 2015) and this shows also in our data: exercises in students' materials were the primary resources for hands-on activities during grammar lessons. Furthermore,those teachers who did not use textbooks in teaching a new topic, usually drew on students' textbooks and workbooks as sources of exercises. Students' materials contain a wide range of texts that are accompanied by explicit instructions for how to use the text. In our second example, the topic of the lesson is syntactic analysis; in this excerpt, the focus is on the exercise that comprises six numbered sentences that, in succession, form a short story. The task 
instructions, however, tell the reader to identify all predicates and subjects in the text (Figure 2).

The instructions address an individual student. In our data, these kinds of texts that address individual students guiding them to perform written activities are typically discussed during or after completing the prescribed task. The introductory chapters in most teachers' guides recommend that teachers organise joint activities around the exercises but whether and how these activities are conducted regarding specific exercises is left for the teacher to decide.

The excerpt is a part of an activity we call a 'checking episode' (cf., Gourlay, 2003). Checking exercises that are completed by students during the lesson or as homework are routine activities in many classrooms (e.g., Pitkänen-Huhta, 2003), and this activity occurs frequently in our data as well. The main purpose of the activity is, first, to check that students have really completed the exercises and, second, to provide the teacher an opportunity to monitor student learning. In addition, the teacher often contributes to the construction of learning opportunities by taking an active role by not only rectifying errors but also correcting misunderstandings and misconceptions revealed by incorrect or imperfect answers. Correct answers, in contrast, are elaborated on less frequently; however, in this episode the teacher further elaborates a correct answer produced by a student.

\section{Extract 2. Vikke and Vilma}

1. ope: "emme saat tästä mịtään selvää Vikke ja Vịlma valittivat."

tch: "we can’t make anything out of this Vikke and Vilma complained."

2. $\quad(2.0)$

3. ope: nyt hei sit etsitää. (.) predikaatti.

tch: now hey let's look for (.) the predicate.

4. $\quad(2.0)$

5. ope: Milli. tch

6. Milli: "emme (.) saa,"
"we (.) can't,"

7. ope: hyvä, (.) "emme saa." 
tch: $\operatorname{good}($.$) "we can’t."$

8. (1.3)

9. ope: mitäs subjektista tossa sanotte.

tch: what do you say about the subject here

10

11. ope: öää (.) Milli.

tch

12. Milli: se on siin samassa se on se äm äm [ee pääte. it is included in it it is the em em [ee ending.

13. ope: [hyvä. (.) eli emme saa? (.) se on predikaatti joka sisältyy subjektiin tch: $\quad[$ good (.) so "we can't?" (.) it is a predicate that is included in the subject

14. koska se (.) tavallaan nyt kuuluu siihen se on se äm äm ee joka? (.) on se persoonapääte sillä tavalla joka because it (.) in a way now belongs to it it is that em em ee that? (.) is the personal ending in that it

15. kertoo ketkä tekevät. (.) hyvä.

tells who are doing. (.) good.

At the beginning of the excerpt, the teacher reads aloud the third numbered item (1. 1) and after a silence (1. 2), she produces a directive etsitään '1et's find'. To be precise, the form is morphologically in the passive voice but it is often pragmatically used to deliver directions in colloquial speech, especially in coaching and instructional contexts (VISK §1654-1655).Thus, the elicit functions as an invitation to a joint activity. The teacher waits for some time (1. 4) before selecting Milli to respond (1. 5). Milli reads aloud the answer (1. 6) and the teacher first produces a positive evaluation hyvä (good) and then repeats the correct answer (1. 8). Here, she treats the correct answer as sufficient and does not further explicate the structure of the predicate, although she could have pointed out that it is made up of the inflected negation verb emme and the inflectional stem of the main verb saa. After a pause, she asks the students what they would say about the subject of this sentence (1.9). She again waits for quite a long time presumably waiting for other volunteers (1. 10) before selecting Milli to respond (1. 11); Milli provides an answer that begins with locating the subject in "that same" and continues to specify the exact location by first enumerating the letters and then naming them as an ending (1. 12). 
The teacher begins to produce a positive evaluation in overlap at the first place in which the answer is recognizable as correct (1. 13); however, this time she does not move straight on to the next item. Instead, she repeats the predicate and explicates that in this case, the predicate is included in the subject and forms a part of it (she mixes up the words subject and predicate by accident) (1. 13-14). Then she repeats the letters that signify the subject and refers to them by using the accurate metalinguistic term persoonapääte (personal ending) (1.15) instead of repeating only the term pääte (ending). Moreover, the teacher makes available the grounds for treating the personal ending as the subject by explicating that it indicates the performer of the action (1. 15). In school grammar, this kind of semantic role is often treated as the main criterion for identifying the subject, and tasks are designed to contain only those subjects that can be identified using that criterion. Finally, the teacher closes the sequence by producing a positive evaluation hyvä (good) (1. 15).

These kinds of checking episodes occur frequently in our data. For teachers, exercises provided by curriculum materials appear as valuable sources of hands-on-activities that enable students to practise different literacy skills. In our data, the majority of checking episodes are related to two main topics of grammar taught at sixth grade: parts of speech and syntactic functions. While teachers could draw on a wide variety of different texts as objects of syntactic analysis, they seem to prefer exercises provided by curriculum materials. In contrast to naturally occurring texts, textbook and workbook exercises are designed to cover all those features of the phenomena that are under scrutiny and only them. Sometimes these kinds of exercises are criticized for prescribing too strictly the activities around them to elicitation and production of determined target forms; they are suspected to limit both teachers and students' agency (e.g., Guerrattaz \& Johnson, 2013). However, production of target forms is not the fundamental purpose of exercises; rather, such production is an outcome of a process of applying knowledge and skills to concrete examples. Thus, the intended affordances of an exercise or task refer to those specific features of text that are designed to enable the students to make use of particular skills and knowledge. 
In this episode and in fact across the whole lesson, the teacher models the use of meta-language by employing accurate linguistic terms in referring to different parts of the text. Moreover, she frequently elaborates on students' answers by emphasizing those features of text that are essential to discern in order to solve the problem set by the task. Thus, she not only evaluates the student answers as correct or incorrect, but also highlights the practices needed for arriving at this result. This indicates that she can disclose the intended affordances of the text by relying on her professional knowledge base. In the field of mathematics education, researchers have been actively engaged in identifying knowledge and skills that enable the teacher to enact mathematical tasks in classrooms (e.g., Ball, Thames \& Phelps, 2008). They have pointed out that task enactment is a complex process that requires in-depth knowledge of several kinds (e.g., Charalambous \& Hill, 2012). In first language and literature education and especially teaching and learning grammar, these kinds of attempts to identify the knowledge and skills that are needed to enact grammatical tasks are yet rare although hands-on activities that involve working on tasks play an essential role in teaching (cf. Rättyä, 2017).

\subsection{Using an exercise on grammar for teaching vocabulary}

Our third example is in some ways like the second: the topic of the lesson is grammar, this time local cases and the episode is part of a checking activity. In this episode, however, reading aloud the written answers is momentarily suspended by a shift from the activity prescribed by the text to another topic and activity: studying vocabulary and explaining word meanings. This shift illustrates the teacher's autonomy to use the text for purposes that are not prescribed by the textbook authors.

In Finnish, nominals are inflected by adding endings to the stem. These endings have functions similar to prepositions in English. In this excerpt, the focus is on a fill-in-the-blank activity students should have completed as homework. The exercise is composed of words written in the nominative case, each followed by an empty slot in which the student is expected to write the answer. The instructions tell the reader to inflect the words according to the model. The model consists of two 
words: the first one is in nominative case and the second one is inflected in the illative case (see Figure 2). Thus, the text strictly prescribes the activity and its outcome. The intended purpose of the task is presumably to illustrate that the illative case has more than one type of ending and to provide students an opportunity to infer the rules that determine the choice between the alternative endings.

Figure 2: The pile (source: Salainen kerho, exercise book, pp. 26)

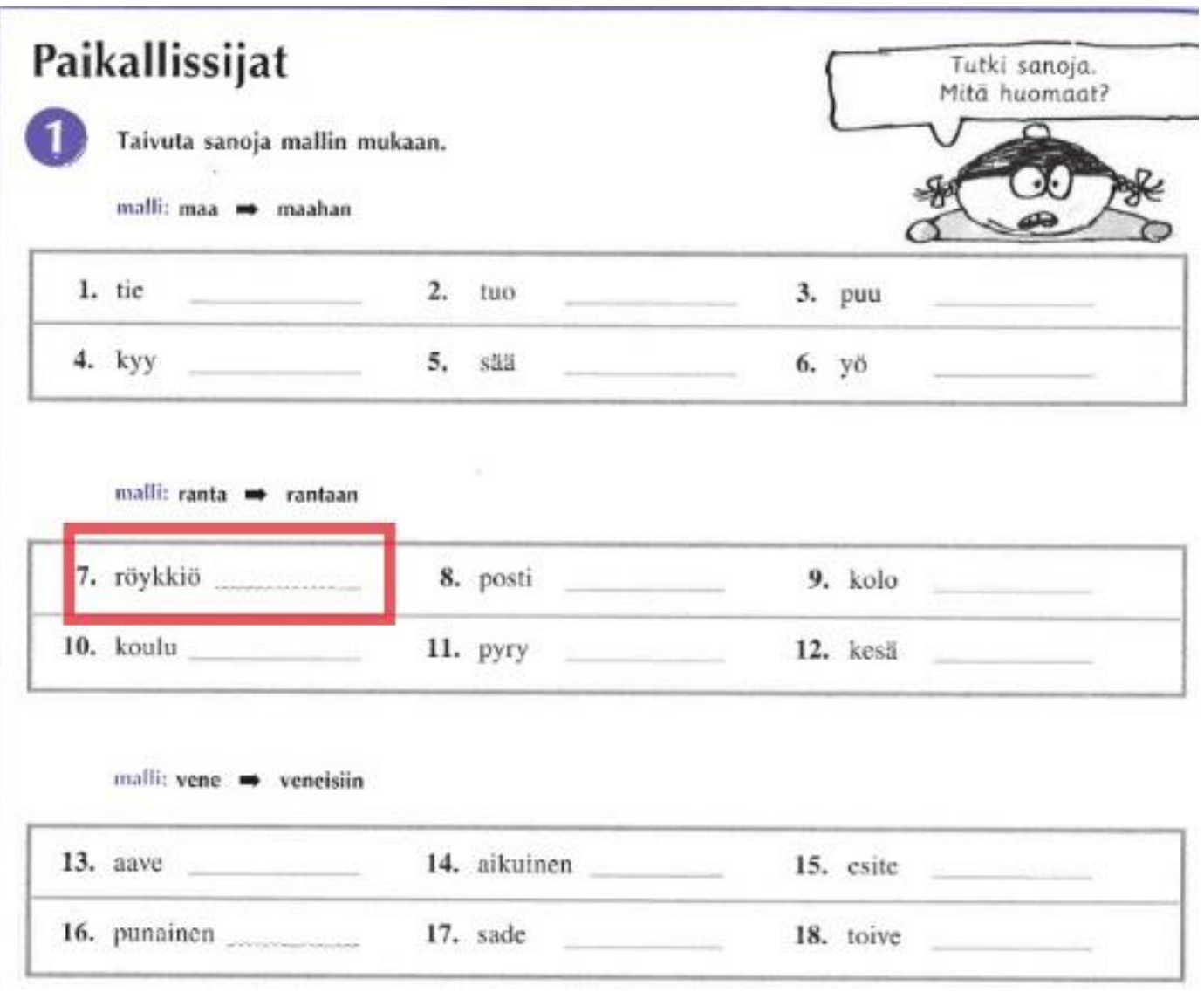

At the beginning of the excerpt, the teacher introduces a shift to the topic of the lesson (1. 1) and reads aloud task instructions from the workbook (1. 3). Then she determines the procedure for proceeding and addresses Sabina as the first speaker (1. 5). The rest of the students are told to answer in succession according to their order of seating. Sabina turns her eyes to the text open at her desk and reads aloud her answer to the first item (1. 6). The activity continues smoothly as each student in turn reads aloud his or her response (omitted from the transcript). For the time being, the teacher treats the provision of correct form as a sufficient answer. Thus, the text is approached in 
terms of task completion prescribed by accompanied instructions. By and large, this kind of activity can be identified with the dominated approach to curriculum materials because production of target form is, itself, treated as a sufficient indication of learning (c.f., Apple \& Christian-Smith, 1991).

\section{Extract 3. The Pile}

1. Tch: nyt ruvetaan kattoo paikallissijoja. now we'll look at locative cases

TchG: workbook $\rightarrow$

2.

3. Tch: "taivuta sanojen. (.) mallin. (.) mukaan"

"decline the words (.) following (.) the example"

4. $\quad(1.0) \times(1.0) \times(0.5)$

TchG: $\quad x-----x$ Sabina

5. Tch: mennää ihan järjestyksessä.=alotetaan vaikka $\quad x$ Sabinasta.

$T \operatorname{ch} G$ :

let's proceed in order. $=$ let's begin with for instance $\mathrm{x}$ Sabina

6. Sabina: "tiehen"

"to the road"

((lines omitted))

7. Kerttu: "röykkiöön"

"to the pile"

TchG: workbook

8.

(.)

9. Tch: $\quad m m()$.$x mikä on muuten röykkiö.$

$\mathrm{mm}(.) \mathrm{x}$ what is a pile by the way

TchG: $\quad x$ students

$10 . \quad(1.0)(($ Pertti viittaa $))$

(1.0) ((Pertti raises his hand))

11. Lauri: auto.

a car

12. Mikko: (-).

13. Tch: $\mathrm{x} \%$ Pertti.

TchG: $\quad x$ Pertti

TchHe: \% nod

14. Pertti: se on niinku semmonen kasa $\%$ jotain

TchHe:

it's some kind of stack of $\%$ something.

15. Tch: $\$() \$.$# jo[o. \quad \mathrm{x} \$$

$\$() \# y e.[s . \quad x \$$ 
TchHa:

TchG:

16. Pertti:

17.

18. Tch: $x$ sitten.

$\mathrm{x}$ then.

TchG: $x$ students

After accepting Kerttu's answer (1. 7) as correct, the teacher raises her eyes from the workbook, which is open at her desk and produces a follow-up question that is marked as a side-sequence by using an utterance particle muuten (by the way) (1. 9). This misplacement marker (Schegloff \& Sacks, 1973) indicates that what follows should be understood as something that departs from the routine progress of the checking episode but is relevant for accomplishing the broader goals of interaction (Jefferson, 1972). Pertti raises his hand right after the teacher has completed her question (1. 10) and after self-selected turns by two students (1. 11 and 12), the teacher selects Pertti to respond using both verbal means, that is, addressing him by name, and embodied means, that is, nodding towards him (1. 13) (c.f., on embodied turn-allocation devices, Kääntä, 2010).

Pertti begins to produce an answer (1. 14) and the teacher nods at the first place in which the answer can be recognized as sufficient. Nodding is a type of response that treats the turn as still in progress and encourages the speaker to continue (Stivers, 2008). Pertti persists and as he stops, the teacher immediately begins to make an indexical gesture that illustrates the shape of a pile (1. 15). However, the teacher does not begin to produce verbal acceptance simultaneously and Pertti appears to interpret the silence to indicate that the teacher treats his answer as insufficient. He begins to specify the explanation by providing an example of what that "something" could be (1. 16). Almost simultaneously, the teacher begins to produce verbal positive feedback (1. 15). Nevertheless, Pertti does not stop, but lowers his voice as if to withdraw from the floor. The teacher bypasses the extension; after a silence (1. 17), she returns to the activity prescribed by the text (1. 18). 
Task instructions printed in the workbook invite the reader to focus on the grammatical form of the items. These items are words that also have lexical meanings. The meanings, however, are not relevant for completing the task as prescribed by the author of the materials. The teacher identifies one of the items as a relatively uncommon word that may not be familiar to all students and exploits the opportunity for students to extend their vocabulary. In other words, the lexicon used in the text embodies pedagogical potential that can be used for teaching vocabulary. This potential is neither explicated in the teacher's guide nor highlighted in students' materials. Thus, its identification and realization depend on the teacher's knowledge of her students' vocabulary and its possible limitations as well as her ability to read the text from multiple perspectives, instead of adopting the use of the text as foregrounded by the task instructions.

This episode illustrates that even fill-in-the-form type of activities that prescribe strictly the activities around them to elicitation and production of determined responses embody affordances that enable their use for other purposes than those prescribed by the authors. However, in the next edition of the curriculum package, the word röykkiö (pile) is replaced by a very common word piha (yard). For native speakers, inflection of familiar words is usually easy even if they are not able to explicate the rules; however, if the word is less familiar, the choice between alternative endings may not be as obvious. Therefore, those responsible for the revisions of the textbook may have thought that choosing the correct ending for such an uncommon word is too challenging. Consequently, the pedagogical potential of the text is diminished and at the same time, curriculum literacy demanded from the teacher is reduced. On the other hand, the intended pedagogical potential, that is, an opportunity to become aware of different illative endings, may be more easily realizable for the students if they do not need to struggle with single words; the purpose of the task is yet to notice that despite the slightly different appearances, all target forms, if correctly inflected, are in illative. Moreover, by examining closely these target forms, it is possible to defer a rule that determines the choice of the ending. It must be also remembered that even very common words can 
be challenging especially for those students who are not native speakers. Thus, the teacher needs to be aware of the limits of the students' vocabulary even if the purpose of the task is not primarily related to extending vocabulary.

\subsection{The text layout as an object of examination}

In contemporary classrooms, teachers usually have an opportunity to utilise different technologies. In our next example students are working on a new topic, different meanings conveyed by the cases and the teacher has projected a page from the students' textbook on the whiteboard. While all students have access to the text in their textbooks, the projection enables the teacher to make use of embodied practices to bring the visual dimension of text into the focus of joint attention. The upper part of the textbook page contains a box titled Sijamuodot (Cases). The box contains short descriptions of the possible meanings of five cases in Finnish. A sample sentence accompanies each description and illustrates the meaning. In the samples, the case endings are highlighted in red (see Figure 3).

Figure 3: Red endings (Source: Kulkuri 6, pp. 76).

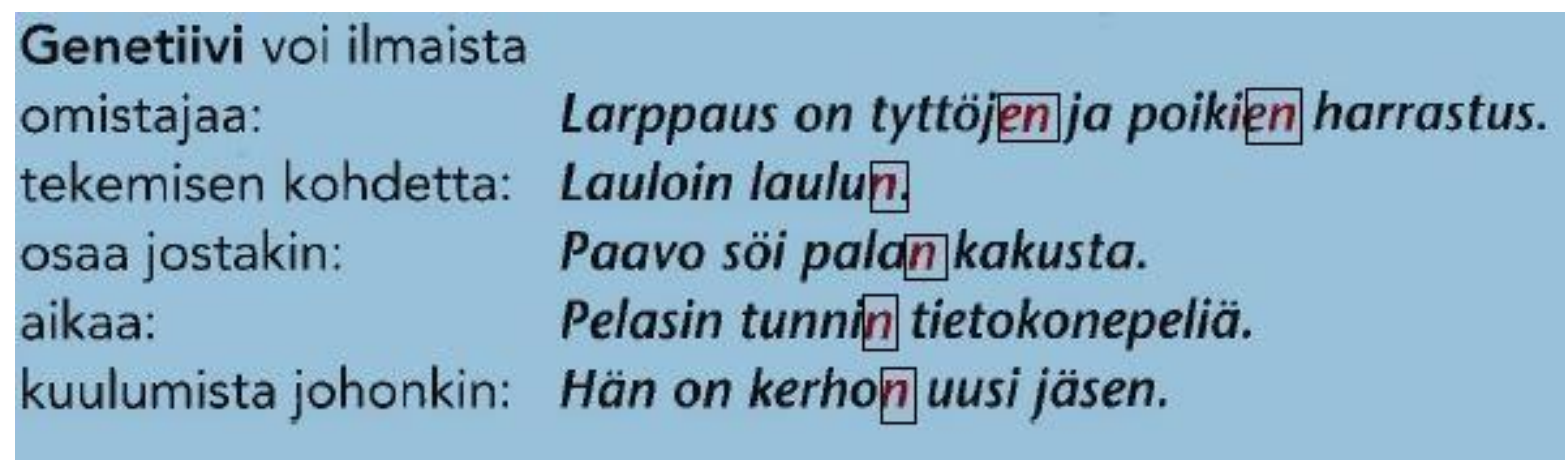

The meaning conveyed by the visual layout is not explicated in the text. Thus, noticing and making sense of the layout is left to the readers. The teacher's guide advises the teacher to invite the students to examine the text in such a way that the different meanings conveyed by the cases in the sample sentences are foregrounded. Case endings are mentioned in the teacher's guide as a secondary focus of interest. The more specific practices to be used in carrying out the suggested 
activity are not offered in the teacher's guide. In this transcript, the abbreviation TchMo denotes teacher's motion in the classroom.

\section{Extract 4. Red endings}

1. Tch: $\quad$ +osaaks joku \% sanoa, (.) miksi tääl + on punasella $\mathrm{x}$ nää kohat $\%$ + is someone able to tell, (.) why these + items here are red

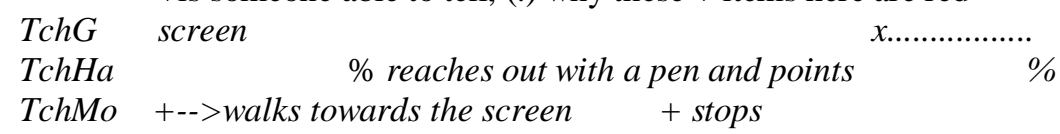

2. $\quad \mathrm{x}(2.0)$

TeaG $\quad x$ students

3. Tch: osaako x joku sanoa miks tääl on punasella laitettu nämä can $\mathrm{x}$ someone tell why these items here are coloured red

Tch $G \quad$..... $x$ screen

4. $\quad \mathrm{x}+(4.5)+$

TchG: $\quad x$ students

TchMo: $\quad+$ walks behind the desk + stops

5. Tch: $\quad$ x osaa (.) ja nyt kuuntele tarkasti koska voi olla (.) että mä kysyn tän $\mathrm{x}$ yes (.) and now listen carefully because I may (.) ask this

TchG: $\quad x$ students

6. kahteen kertaan tän jälkee $\mathrm{x}(0.4)$ miks * nää on punasella laitettu * [tän]ne two times after this time $\mathrm{x}(0.4)$ why $*$ these items are put red $*$ [he]re

$T c h G$

TchHa $x$ book

7. Henri:

* grabs the ruler

*points at the book

[okeih]

8. Tch: nää $x$

these $\mathrm{x}$

TchG x screen

9.

$(2.0) * \mathrm{x}(1.0)$

TchHa: * moves the ruler from the book

10. Tch: ja tähän vastaa >ystävällisesti< henkilö nimeltään:: (0.6) Uuno.*

TchHa: and the answer is > kindly< provided by a person called:: (0.6) Uuno. *

* sets the ruler on the table

11. Uun: $\quad x$ no ne on niinku jotenki (ne) (.) tunnus tai semmone $\mathrm{x}$ well they are somehow like the (.) sign or something

TchG: $\quad x$ whiteboard

12. Tch: $\quad \mathrm{x} \downarrow$ nii genetiivin $\mathrm{x}$ tunnus on än. $\mathrm{x}($ (.) hyvä $\mathrm{x}($.$) ja nyt tulee kysymys (.) joka$ $\mathrm{x} \downarrow$ yeah the sign $\mathrm{x}$ of genitive is en $\mathrm{x}$ (.) good $\mathrm{x}$ (.) and now I'll ask a question (.) which

$T \operatorname{ch} G$ :

$x$ students

$x$ screen

$x$......... $x$ students 
13. tulee pommina? (0.4) mikä on (.) genetiivin $\uparrow$ tunnus, drops as a bombshell? (0.4) what is (.) genitive’s $\uparrow$ sign

14. Emi: ${ }^{\circ}{ }^{\circ}{ }^{\circ}$

${ }^{\circ} e n^{\circ}$

15.

16. Tch: Anni.

17. Ann: än

en

18. Tch: mikä on genetiivin $\uparrow$ tunnus (.) Aapo

what is genitive's $\uparrow$ sign (.) Aapo

19. Aap: än

en

20. Tch: <mikä on> genetiivin tunnus $<$ what is $>$ genitive's sign

21. Joo: ä[n]

$e[n]$

22. Tch: [Vil]ma

23. Vil: ${ }^{\circ}$ än ${ }^{\circ}$

en

24. Tch: än *(.) $x$ +entäs ku täällä lukee että (2.5) en \& (1.0) ni (1.0) m- (1.5)

$e n *(.) \quad \mathrm{x}+$ and how about as here it is written that (2.5) en (1.0) so (1.0) h- (1.5)

TchG $\quad$.... $x$ screen

TchMo * turns to screen, takes a step closer

TchHa + points with pen)

AntHa

+ points with pen)

\& raises hand

Figure 4: The teacher points at red endings
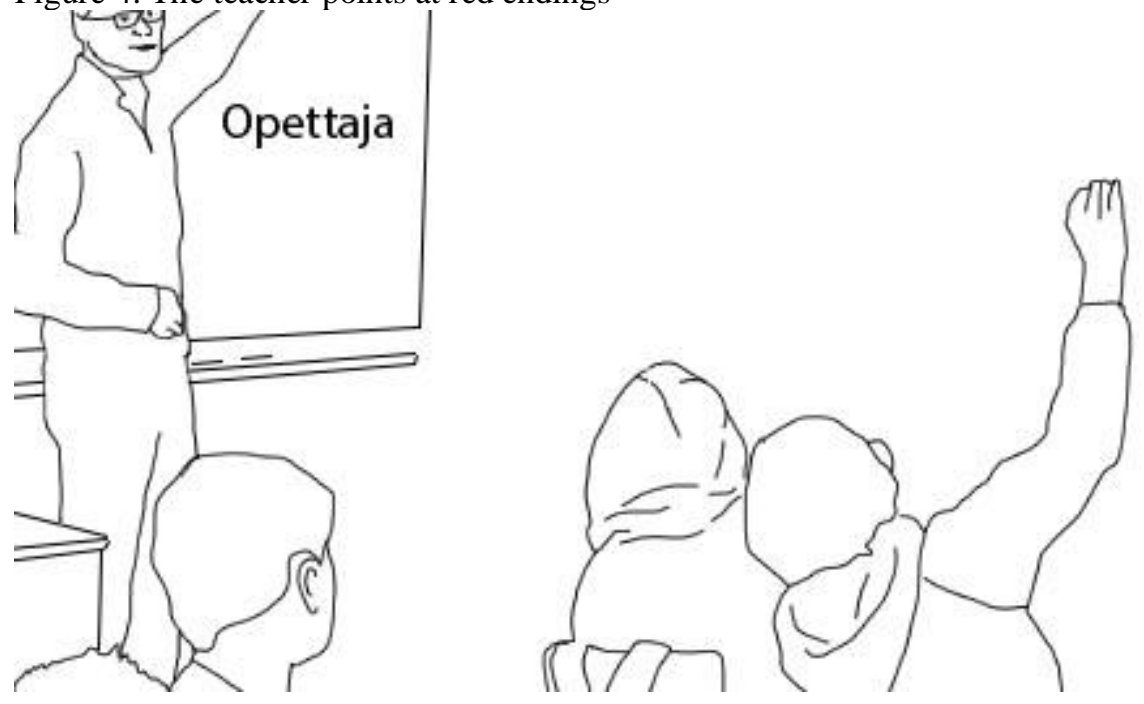
25.

ni (0.6) m- miten nii se on än se genetiivi=ku tääl lukee en (.)

then (0.6) how can it be $e n$ this genitive=because here it says en (.)

26. miks tääl on tää eeki v- laitettu * why is this $e$ here put too*

TchHa

* points to Anton with the pen

27. Anton: \& se (o-) (.) tekee monikon

$\&$ it (i-) (.) makes plural

AntHa \& hand down

28. Tch: $\quad \mathrm{x} \downarrow$ nii, $=$ monikos $*$ sinne $\mathrm{t}$ - saattaa tulla $\mathrm{x}$ jotai vokaaleita (.) kaveriks

$\mathrm{x} \downarrow$ right,$=$ in plural $*$ there $\mathrm{i}$ - might come $\mathrm{x}$ some vowels (.) accompanied

TchG $x$ screen $x$ desk

TchMo * turns and walks behind his desk

29. $\quad \mathrm{x}(1.0)$ hyvä, (0.6) sitten (.) <partitiivi>

TchG: $\quad x$ book

$\mathrm{x}$ (1.0) good, (0.6) then (.) <partitive>

At the beginning of this excerpt, the teacher directs students' attention to the layout of the text both with an embodied practice, pointing, and an accompanying indexical pronoun nä̈ (these) (cf. Jakonen, in press; Kääntä, 2014). The turn is formatted as a polar question that inquires about students' ability to explain the meaning conveyed by the graphic layout of the sample sentences (l. 1). After a pause during which the teacher monitors the class, apparently giving students time to consider the answer (1.2), he repeats the question, accompanied by pointing that clarifies the precise referents of the indexical pronouns (1. 3). During the ensuing silence, the teacher turns around, walks to his desk and turns again to face the students (1. 4). Some students have raised their hands, and the teacher answers his own question by recognising that some students are indeed able to provide an answer (1.5).

Then the teacher urges students to listen carefully and points out that he may repeat the following question several times (1. 5). In this way, he indicates that students are expected to know and remember that information. Thus, he formulates a question that invites the students to explain the meaning conveyed by the red font used in the sample (lines 6 and 8). Again, he uses an indexical pronoun nä̈̈ (these), while pointing (1. 6). During the following three-second silence, the teacher 
turns to look at the students (1. 9). He nominates Uuno who has volunteered by raising his hand and then turns to look at the screen (1. 10). Uuno provides an explanation (1. 11), and the teacher accepts it by producing response particle nii (yes). According to Sorjonen $(2001,58)$, nii confirms the candidate answer as factual knowledge that is shared by the participants and projects continuation. Next, the teacher paraphrases the answer by replacing the indexical pronoun sen (its) by genetiivin (genitive's); this response transforms it into a complete sentence, closes the sequence and produces a positive evaluation, hyvä (good) (1. 12).

After a brief but audible pause, the teacher initiates another question-answer sequence. The andpreface at the beginning of the turn (1.12) links the question to the previous question-answer pairs. Moreover, it indicates that the question belongs to a particular series of questions that constitutes the teacher's agenda (cf., Heritage \& Sorjonen, 1994). The question preface announces a shift to a distinct turn-allocation system. In this classroom, a question that "drops as a bombshell" is used as a playful reference to a question to which any of the students may be selected to answer. Apparently, this kind of interactional practice is frequently used by this teacher and the students play along with it. Thus, the announcement informs the students that the teacher expects everyone to be able to provide the correct answer; thereby, she emphasizes the significance of the information requested (l. 12-13). The teacher transforms the proposition that he uttered earlier (1. 12) into a question and asks this question three times (1. 13, 18 and 20).

After receiving the correct answer three times (1. 17, 19 and 23) and ignoring two self-selected answers (1. 14 and 21), the teacher ratifies the correct answer by repeating it (1.24) and continues to produce the next question. A syntactic preface precedes it, topicalizing an observation that appears as contradictory to what was just proposed (1.24). Simultaneously, the teacher turns to face the whiteboard and points to the last sample sentence with the pen (Fig. 4). In this sentence, the two last letters, $e$ and $n$, of the words tyttöjen (girls') and poikien (boys') are written with a red font. This is followed by a rhetorical question that challenges the accuracy of the just-accepted claim concerning 
genitive's ending and a question asking the students to provide an explanation for the latter observation (1. 24-27). The teacher selects Anton to answer by pointing at him with the pen (1. 27). Anton provides an answer (1.28) and the teacher confirms it with response particle nii. In reformulating the answer (1.29), the teacher hints that in addition to letter $e$ illustrated in the text, there are also other vowels that may accompany letter $n$ in plural genitive. After a short silence, the teacher closes the sequence with a positive evaluation hyvä (good) and moves on to the next case, the partitive (1. 30).

In this example, the text conveys information about cases both explicitly and by means of visual layout. The text itself does not prescribe any specific way of using it. The teacher's guide determines the meanings of the cases as the primary focus of the chapter and invites the teacher to engage students in examining the text to figure out the meanings of cases in the sample sentences but it does not specify how to carry out the activity of examination in practice; however, the potential meanings conveyed by different cases are disclosed in the text and the sample sentences illustrate those meanings. Consequently, the suggested examination into different meanings of the cases is an issue of reading aloud the text rather than inferring potential meanings from the sample sentences. Case endings, instead, are not described or even mentioned in the text but only manifested in the visual layout of the samples. Instead of asking students questions that they can answer by reading aloud the text, the teacher identifies the pedagogical potential embodied by the visual layout and brings it into the focus of joint attention as a feature worth noticing and comprehending. In inviting students to interpret the meanings conveyed by the graphic layout, he models a strategy of reading the text as a multimodal artefact. We suggest that the teacher's professional knowledge base, his content knowledge and pedagogical content knowledge in particular, enabled him to identify and realize the pedagogical potential embodied by the graphical layout. 


\section{Discussion}

In this article, we analysed four instances of classroom interaction that illustrate different ways in which the teacher discloses and realises the pedagogical potential of curriculum materials in enacting the curriculum in the classroom. Our analysis indicates that although curriculum materials explicitly prescribe certain ways of using the texts, these intended uses do not determine the actual uses of texts in classrooms. First, the teacher may treat the content of a text or the production of the target forms as self-sufficient objects of learning. Second, s/he can attempt to carry out the activities in accordance with the guidelines provided by the materials and emphasize those interpretations and procedures that are specifically afforded by the design of that text. Third, s/he may rely on his or her knowledge to find alternative ways of utilising the text. Altogether, these examples demonstrate that teachers can draw on curriculum materials in different ways and the different ways in which they realize the pedagogical potential of the materials results in the construction of different learning opportunities.

Each text affords multiple readings and teachers may follow the guidelines provided by the authors but they can also use the texts for other purposes. In calling for particular kinds of speaking and writing in response to the text as well as in reacting to students' initiatives and responses in certain ways, the teacher enables, emphasises and reinforces particular readings and interpretations of texts while omitting or sanctioning others. Some of the possible uses of the texts may be pedagogically less appropriate than others or even ethically problematic. The teacher may reproduce and reinforce stereotypical views on gender provided by the text instead of challenging them (Sunderland et al., 2001), or treat the information provided by the text as factual and ask students to memorize it without seeking alternative perspectives or challenging its content or its underlying assumptions even in teaching a school subject such as philosophy that should fundamentally aim at cultivating critical thinking (Pinto, McDonough \& Boyd, 2011). Pedagogically appropriate or efficient use of text depends, naturally, on the aims and content of teaching; thus, it cannot be unambiguously 
defined. Nevertheless, we argue that texts provided by curriculum materials are not equally suited for all purposes and in an extreme case, a particular way of treating the text may result in ethically problematic interpretations, as illustrated by Sunderland et al. (2001). Another example of pedagogically less appropriate way of treating the text is illustrated in our first example in which the teacher treats a simplified model provided by the textbook as a generalizable account that applies across different modalities.

In this study, we focused on teachers curriculum use in the context of an enacted curriculum and, more specifically, literacy events during which the participants observably orient to curriculum materials. The aggregate effect of curriculum materials upon teaching and learning is naturally not restricted to these events: curriculum materials may influence selection of topics and their sequencing across lessons. Moreover, our analysis focused on participants' observable actions and thought processes underlying the actions were not brought into focus. To develop a synoptic view on teachers' curriculum use in first language and literature education, in-depth case studies that combine detailed analysis of classroom interaction with interviews that chart teachers' thinking during different phases of teaching-learning process would be important.

\section{Conclusions}

Production and use of various kinds of texts has been recognised as an essential professional practice in many institutional contexts (e.g., Femo-Nielsen, 2012; Mondada \& Svinhufvud, 2016). Consequently, mastering the core literacy practices characteristic to a profession is a key competence in many workplace settings. In first language and literature classrooms, a great deal of interaction between the teacher and the students can be characterised as talk about texts. In participating in these literacy events by reading, writing, listening and talking about texts, students 
are socialised into larger cultural practices that involve the use of written and spoken language (e.g., Barton \& Hamilton, 1998).

Ready-made curriculum materials are designed to assist the teacher to select texts and organise pedagogical activities that are consistent with the aims and principles defined in the national core curriculum. As is the case for any tool effective use of these materials demands expertise (Ball \& Feiman-Nemser, 1986; Ben-Peretz, 1990; Wells, 1999). Teachers;' ability to disclose the pedagogical potential of the texts determines, in large part, the ways in which curriculum materials feature in enacted curriculum. Enacted curriculum, in turn, largely determines what kind of learning opportunities students encounter (e.g., Remillard \& Heck, 2014). Thus, the competences that enable the teacher to make informed and well-grounded decisions about the use of curriculum materials are an essential element of teachers' expertise.

Altogether, our findings indicate that the realisation of the pedagogical potential of texts embodied by curriculum materials is largely contingent upon a teacher's ability to disclose the potential and transform it into actual practices and activities that, in turn, create learning opportunities for the students. Previous studies have shown that while features of the materials as well as the context inevitably affect teachers' curriculum use (e.g., Haggarty \& Pepin, 2002), it is also influenced by teacher-related factors such as teachers' teaching experience (e.g., Grossman \& Thompson, 2008; Taylor, 2013), their attitudes towards curriculum materials (e.g., Drake \& Sherin, 2005; Remillard \& Bryans, 2007), as well as breadth and depth of their pedagogical content knowledge, subject knowledge and their knowledge of curriculum, students and context (e.g., Pinto, McDonough \& Boyd, 2011; Valencia, Place, Martin \& Grossman, 2006). In addition, it has been suggested that to use curriculum materials effectively, teachers need a special kind of expertise that enables them to read the materials analytically and critically to identify their pedagogical potential as well as to adapt and modify the texts and activities according to the needs of particular students and teaching situations (e.g., Brown, 2009; Brown \& Edelson, 2003). Thus, it is easy to understand that 
deploying curriculum materials in ways that support student learning is not a straightforward task for teachers (e.g., Ball \& Feiman-Nemser, 1989; Pinto, McDonough \& Boyd, 2011; Valencia, Place, Martin \& Grossman, 2006).

The currently emergent sociocultural approach to teaching and learning (e.g., Panofsky, 2012; Wells, 1999) has brought learning environments into the focus of educational research. Studies influenced by socio-cultural theories often emphasise the role of material, conceptual, cognitive and representational tools, artefacts and technologies as resources that participants may draw on and use in different ways and for different purposes (e.g., Hutchins, 1995; Säljö, 2008). Thus, the sociocultural approach could provide a feasible framework for analysing the role of texts in teaching. Educational researchers who apply such theories, however, tend to juxtapose innovative and traditional learning environments and focus mainly on the former, in other words, out-of-school contexts or school contexts known for innovative pedagogical practices and technologies (e.g., Kumpulainen, Mikkola \& Jaatinen, 2014; Rajala, 2016). Ready-made, printed curriculum materials are considered characteristic of more traditional learning environments and have even come to symbolize so-called traditional classroom activities that are claimed to promote the transmission of or, at best, a superficial rearrangement of information (Wells, 1999).

However, we argue that regardless of the origin of the texts and suggested activities, similar competences are required of the teachers in disclosing their pedagogical potential and transforming it into enacted curriculum that provides learning opportunities for students. While teachers at least in Finland have significant autonomy in choosing the materials they use from a wide variety of available resources or creating themselves the materials they need as well as selecting texts and developing pedagogical activities connected to them (e.g. Tainio \& Grunthal, 2012), it should be recognized that this is a time-consuming process that requires in-depth knowledge of several kinds (Ben-Peretz, 1990). Especially primary teachers, who are responsible for teaching all school subjects for their students on grades 1-6 in Finnish comprehensive schools, cannot be expected to 
have resources to develop all the materials they need themselves or collect them from different sources. If we agree with Grossman, McDonald, Hammerness and Ronfeldt (2008) that teachers should be prepared in ways that are aligned with the realities of working life, teacher education programmes should offer prospective teachers opportunities to learn to use curriculum materials effectively.

Following Taylor (2013), we argue that instead of glorifying or rejecting ready-made curriculum materials, teacher education programmes should educate teachers who have competences to identify and realize the pedagogical potential in all kinds of materials and who also have courage to take a critical view of the materials. Previous studies have shown that prospective teachers' ability to use curriculum materials can be effectively supported by providing them with opportunities to engage in analysing curriculum materials and to practise their use as well as to observe experienced teachers using them (e.g., Forbes \& Davis, 2008; Schwartz et al., 2008). Some researchers have also suggested that curriculum materials could themselves be educative (e.g., Ball \& Cohen, 1996). Educative curriculum materials could support teachers in developing the knowledge base needed for successful teaching as well as help them to anticipate and interpret students' responses in relation to particular activities and suggest ways of dealing with students' ideas (Davis \& Krajic, 2005). Moreover, educative curriculum materials could explicate the ideas that underlie the texts and suggested activities, discuss their strengths and weaknesses and encourage teachers to adapt and modify them to better suit to their own and their students' needs (Drake, Land \& Tyminski, 2015). By supporting prospective teachers' ability to use curriculum materials analytically and critically, we enhance their professional autonomy and agency.

\section{References}

Curriculum materials mentioned: 
Haviala, A., Helin, E., Keisala-Ilomäki, U., Katajamäki, M. \& Siter, M. (2008). Kulkuri 6.

Äidinkieli ja kirjallisuus. [The Vagabond 6. Mother tongue and literature. ]Helsinki: WSOY.

Wäre, M., Töllinen, M. \& Koskipää, R. (2002). Salainen kerho 6. Äidinkielen ja kirjallisuuden peruskirja. [The Secret Club 6. The basic book for mother tongue and literature education.]

Helsinki: WSOY.

Wäre, M., Töllinen, M. \& Koskipää, R. (2004). Salaisen kerho harjoitusvihko 6. [The exercise book of the Secret club]. Helsinki: WSOY.

Research literature

Apple, M. (1986). Teachers and texts. A political economy of class and gender relations in education. New York: Routledge \& Kegan Paul.

Apple, M. \& Christian-Smith, L. (1991). The Politics of Textbook. In M.W. Apple \& L.K. Christian-Smith (Eds.) The politics of the textbook (pp. 1-22). London: Routledge.

Atjonen, P., Halinen, I., Hämäläinen, S., Korkeakoski, E., Knubb-Manninen, G., Kupari, P., Mehtäläinen, J., Risku, A-M., Salonen, M. \& Wikman, T. (2008). Tavoitteista vuorovaikutukseen. Perusopetuksen pedagogiikan arviointi. [From goals to interaction. Evaluation of pedagogy in Finnish basic education]. Koulutuksen arviointineuvoston julkaisuja 30. Retrieved 15.1.2017 from https://karvi.fi/app/uploads/2014/09/KAN_30.pdf

Baker, C. \& Freebody, P. (1989). Talk around text: constructions of textual and teacher authority in classroom discourse. In S. de Castell, A. Luke \& C. Luke (Eds.) Language, authority and criticism: Readings on the school textbook (pp. 263-283). London: Falmer Press. 
Ball, D.L \& Cohen, D.K. (1996). Reform by the Book: What is: Or Might Be: The Role of Curriculum Materials in Teacher Learning and Instructional Reform? Educational Researcher $25(9), 6-8$.

Ball, D.L. \& Feiman-Nemser, F. (1988). Using textbooks and teachers' guides: A dilemma for beginning teachers and teacher educators. Curriculum Inquiry, 18, 401-423.

Ball, D.L \& Forzani, F.M. (2009). The Work of Teaching and the Challenge for Teacher Education. Journal of Teacher Education 60 (5), 497-511.

Ball, D.L., Thames, M.H., \& Phelps, G. (2008). Content knowledge for teaching: What makes it special? Journal of Teacher Education 59, 389-407.

Barton, D. (2007). Literacy: An Introduction to the Ecology of Written Language. $2^{\text {nd }}$ edition. Oxford: Blackwell.

10. Barton, D. \& Hamilton, M. (1998). Local Literacies: Reading and Writing in One Community. London: Routledge.

Benhur Oral, S. (2013). What is Wrong with Using Textbooks in Education? Educational Philosophy and Theory 45 (3), 318-33.

Ben-Peretz, M. (1990). The Teacher-Curriculum Encounter. Freeing Teachers from the Tyranny of Texts. New York: State University of New York Press.

Ben-Peretz, M. (2010). Curriculum Use in the Classroom. In E. Baker, B. McGaw \& P. Peterson (Eds.), International Encyclopedia of Education. ${ }^{\text {rd }}$ Edition (pp. 248-354). Oxford: Elsevier.

Brown, M. (2009). The Teacher-Tool Relationship: Theorizing the Design and Use of Curriculum Materials. In J. Remillard, G. Lloyd \& B. Herbel-Eisenmann (Eds.), Mathematics Teachers at Work: Connecting curriculum materials and classroom instruction (pp. 17-36). New York: Taylor \& Francis. 
Brown, M. \& Edelson, D.C. (2003). Teaching as Design: Can we better understand the ways in which teachers use materials so we can better design materials to support their changes in practice? Research Report, Center for Learning Technologies in Urban Schools.

Collopy, R. (2003). Curriculum Materials as Professional Development Tool: How a Mathematics Textbook Affected Two Teachers’ Learning? The Elementary School Journal 103 (3), 287311.

Davis, E.A. \& Krajcik, J.S. (2005). Designing Educational Curriculum Materials to Promote Teacher Learning. Educational Researcher 34 (3), 3-14.

Drake, C., Land, T.J. \& Tyminski, A.M. (2014). Using Educative Curriculum Materials to Support the Development of Prospective Teachers' Knowledge. Educational Researcher 43, 154-162.

Drake, C. \& Sherin, M.G. (2005). Practicing Change: Curriculum Adaptation and Teacher Narrative in the Context of Mathematics Education Reform. Curriculum Inquiry 36 (2), 153-187.

Drew, P. (1997). 'Open' class repair initiators in response to sequential sources of troubles in conversation. Journal of Pragmatics 28, 69-101.

Femo-Nielsen, M. (2012). Using artifacts in brainstorming sessions to secure participation and decouple sequentiality. Discourse Studies 14 (1), 87-109.

Forbes, C. \& Davis, E.A. (2008). The Development of Preservice Elementary Teachers'` Curricular Role Identity for Science Teaching. Science Education 92 (5), 909-940.

Gourlay, L. (2005). OK, who's got number one? Permeable Triadic Dialogue, covert participation and the construction of checking episodes. Language Teaching Research 9 (4), 403-422.

Grossman, P. \& McDonald, M. (2008). Back to the Future: Directions for Research in Teaching and Teacher Education. American Educational Research Journal 45 (1), 184-205. 
Grossman, P., McDonald, M., Hammerness, K. \& Ronfeldt, M. (2008). Dismantling dichotomies in teacher education. In M. Cochran-Smith \& S. Feiman-Nemser, J. McIntyre \& K. Demers (Eds.), The handbook of teacher education: A project of the Association of Teacher Educators 3rd Edition (pp. 243-248). New York, NY Macmillan

Grossman, P. \& Thompson, C. (2008). Learning from curriculum materials: Scaffolds for new teachers? Teaching and Teacher Education 24, 2014-2026.

Guerrettaz, A.M. \& Johnston, B. (2013). Materials in the Classroom Ecology. The Modern Language Journal 97 (3), 779-796.

Haakana, M. (2011). "Mitä" ja muut avoimet korjausaloitteet. ["What" and other open repair initiators] Virittäjä 115 (1), 36-67. Retrieved 15.1.2017 from

\section{http://journal.fi/virittaja/article/view/4034.}

Haggarty, L. \& Pepin, P. (2002). An Investigation of Mathematics Textbooks and Their Use in English, French and German Classrooms: who gets an opportunity to learn what? British Educational Research Journal 28 (4), 567-590.

Hepburn, A. \& Bolden, G.B. (2013). The Conversation Analytic Approach to Transcription. In J. Sidnell \& T. Stivers (Eds.) Handbook of Conversation Analysis. Blackwell Publishing Ltd: UK.

Heritage, J. \& Sorjonen, M.-L. (1994). Constituting and maintaining activities across sequences: and-prefacing as a feature of question design. Language in Society 23, 1-29.

Hill, H.C. \& Charalambous, C.Y. (2012). Teaching (Un)Connected Mathematics: Two Teachers' Enactment of the Pizza Problem. Journal of Curriculum Studies 44 (4), 467-487.

Hutchins, E. (1995). Cognition in the wild. Cambridge: MIT Press. 
Jefferson, G. 1972. Side-sequences. In D. Sudnow (Ed.) Studies in Social Interaction (pp. 294338). New York: Free Press.

Jakonen, T. (2015). Handling knowledge: Using materials to construct and interpret information requests. Journal of Pragmatics 89, 100-112,

Jakonen, T. (in press). The environment of a bilingual classroom as an interaction resource. Accepted for publication in Linguistics and Education.

Karvonen, U., Tainio, L. \& Routarinne, S. (accepted). Oppia kirjoista. Systemaattinen katsaus suomalaisten oppimateriaalien tutkimukseen. [Learning from books. A systematic review of research on curriculum materials in Finnish basic education.]

Karvonen, U., Tainio, L., Routarinne, S. \& Slotte, A. (2015). Tekstit selitysten resurssina oppitunnilla. [Texts as resources for explanations in classroom interaction] Puhe ja Kieli 35, 187-209. http://ojs.tsv.fi/index.php/pk/article/view/55388, accessed 15.1.2017

Koutselini, M. (2012). Textbooks as Mechanisms for Teacher's Sociopolitical and Pedagogical Alienation. In H. Hickman \& B.J. Porfilio (Eds.) The New Politics of Textbook: Problematizing the Portrayal of Marginalized Groups in Textbooks (pp. 3-16). Rotterdam: Sense Publishers.

Kumpulainen, K., Mikkola, A. \& Jaatinen, A.-M. (2014). The chronotopes of technology-mediated creative learning practices in an elementary school community. Learning, Media and Technology 39, 53-74.

Kunitz, S. (2015). Scriptlines as emergent artifacts in collaborative group planning. Journal of Pragmatics 76, 135-149. 
Kääntä, L. (2010). Teacher turn-allocation and repair practices in classroom interaction: $a$ multisemiotic perspective. Jyväskylä studies in humanities 137. Jyväskylä: Jyväskylän yliopisto.

Kääntä, L. (2014). From noticing to initiating correction: students' epistemic displays in instructional interaction. Journal of Pragmatics 66, 86-105.

Love, E. \& Pimm, D. (1996). `This is so`: a text on texts. In A.J. Bishop, K. Clements; C. Keitel; J. Kilpatrick \& C. Laborde (Eds.) International Handbook of Mathematics Education Part 1. (pp. 371-409). Dordrecht: Kluver Academic Publishers.

Luke, A. (1988). Literacy, Textbooks and Ideology: Postwar Literacy and the Mythology of Dick and Jane. London:Falmer Press.

Majlesi, A.R. \& Broth, M. (2012). Emergent learnables in second language classroom interaction. Learning, Culture and Social Interaction 1 (3-4), 193-207.

Martin, J.R. \& Rose, D. (2008). Genre Relations: mapping culture. London: Oakville.

McHoul, A. (1978). The Organization of Turns at Formal Talk in the Classroom. Language in Society 7, 183-213.

Mondada, L. (2014). Conventions for multimodal transcription. https://franz.unibas.ch/fileadmin/franz/user_upload/redaktion/Mondada_conv_multimodality. pdf , accessed 15.1.2017.

Mondada, L. \& Svinhufvud, K. (2016). Writing-in-interaction: Studying writing as a multimodal phenomenon in social interaction. Language and Dialogue 6 (1), 1-53.

Panofsky, C. P. (2012). Sociocultural research on learning. In N.M. Seel (Ed.) Encyclopedia of the sciences of learning, (pp. 3131-3135). London: Springer. 
Peräkylä, A. (2004). Reliability and validity in research based on naturally occurring social interaction. In D. Silverman (Ed.). Qualitative research: Theory, method and practice. $2^{\text {nd }}$ edition, pp. 283-304. London: Sage.

PIRLS $(2011)=$ Progress in International Reading Literacy Study. International Results in Reading. Retrieved 1.9.2016 http://timssandpirls.bc.edu/pirls2011/downloads/P11_IR_FullBook.pdf.

Pinto, L.E., McDonough, G.P. \& Boyd, D. (2011). High School Philosophy Teachers` Use of Textbooks: Critical Thinking or Teaching to the Text? Journal of Curriculum and Instruction $5(2), 45-78$.

Pitkänen-Huhta, A. (2003). Texts and interaction: literacy practices in the EFL classroom. Jyväskylä: University of Jyväskylä.

Rajala, A. (2016). Toward an agency-centered pedagogy. A teacher's journey of expanding the context of school learning. University of Helsinki, Faculty of Behavioral Sciences, Department of Teacher Education, Research Report 395.

Remillard, J.T. (1999). Curriculum Materials in Mathematics Education Reform: A Framework for Examining Teachers' Curriculum Development. Curriculum Inquiry 29 (3), 315-342.

Remillard, J.T. (2005). Examining Key Concepts in Research on Teacher's Use of Mathematics Curricula. Review of Educational Research 75 (2), 211-246.

Remillard, J.T. \& Bryans, B.M. (2007). Teachers`' Orientations toward Mathematics Curriculum Materials: Implications for Teacher Learning. Journal of Research in Mathematics Education 35 (5), 352-388.

Remillard, J.T. \& Heck, D.J. (2014). Conceptualizing the curriculum enactment process in mathematics education. ZDM Mathematics Education 46, 705-718. 
Rättyä, K. (2017). Kielitiedon didaktiikkaa. Kielentäminen ja visualisointi sanaluokkien ja lauseenjäsenten opetusmenetelminä. [Pedagogical content knowledge in teaching metalinguistic awareness. Languaging approach and visualisations as teaching methods for word classes and sentence constituents] University of Helsinki, Faculty of Educational Sciences Department of Teacher of Education Helsinki Studies in Education 1.

Sawyer, R.K. (2004). Creative Teaching: Collaborative Discussion as Disciplined Improvisation. Educational Researcher 33 (2), 12-20.

Schegloff, E. \& Sacks, H. (1973). Opening Up Closings. Semiotica 4, 289-327. DOI: 10.1515/semi.1973.8.4.289

Schwartz, C.V., Gunckel, K.L; Smith, E. L., Covitt, B.A., Bae, M., Enfield, M. \& Tsurusaki, B.K. (2008). Helping Elementary Preservice Teachers Learn to Use Curriculum Materials for Effective Science Teaching. Science Education 92 (2), 345-377.

Selting, M. (1996). Prosody as an activity-type distinctive cue in conversation: the case of so-called "astonished" questions in repair initiation. In. E. Couper-Kuhlen \& M. Selting (Eds.) Prosody in conversation (pp. 231-270). Cambridge University Press: Cambridge.

Sert, O. (2011). "Epistemic status check" as an interactional phenomenon in instructed learning settings. Journal of Pragmatics 46, 13-28.

Sherin, M.G. \& Drake, C. (2009). Curriculum strategy framework: investigating patterns in teachers' use of a reform-based elementary mathematics curriculum. Journal of Curriculum Studies 41 (9), 467-500.

Sidnell, J. \& Stivers, T. (Eds.) (2013). Handbook of Conversation Analysis. Blackwell Publishing Ltd.: UK. 
Snyder, J., Bolin, F., \& Zumwalt, K. (1992). Curriculum implementation. In P.W. Jackson (Ed.), Handbook of research on curriculum (pp. 402-435). New York: Macmillan

Sorjonen, M.-L. (2001). Responding in conversation: A study of response particles in Finnish. Pragmatics \& Beyond New Series 70. Amsterdam: John Benjamins

Sosniak, L.A. \& Stodolsky, S.S. (1993). Teachers and Textbooks: Materials Use in Fourth-Grade Classrooms. The Elementary School Journal 93 (3), 249-275.

Stein, M.K., Remillard, J.T. \& Smith, M.S., (2007). How Curriculum Influences Student Learning. In F.K. Lester (Ed.). Second handbook of research on mathematics teaching and learning (pp. 319369). Greenwich, CT: Information Age Publishing

Stivers, T. (2008). Stance, Alignment, and Affiliation During Storytelling: When Nodding Is a Token of Affiliation. Research on Language \& Social Interaction 41 (1), 31-57.

Streeck, J., Goodwin, C. \& LeBaron, C. (2011). Embodied Interaction in the Material World: An Introduction. In J. Streeck, C. Goodwin \& C. LeBaron (Eds.) Embodied Interaction. Language and the Body in the Material World (pp. 1-27). Cambrige: Cambridge University Press.

Sunderland, J., Rahim, F.A., Leontzakou, C. \& Shattuck, J. (2001). From Bias "In the Text" to "Teacher Talk Around the Text". An Exploration of Teacher Discourse and Gendered Foreign Language Textbook Texts. Linguistics and Education 11 (3), 251-286.

Säljö, R. (2008). Lärande i praktiken: ett sociokulturellt perspektiv. [Learning in practice: A sociocultural perspective]. Stockholm: Norstedts akademiska.

Tainio, L. (forthcoming). Studying the Use of Textbook in the Activity of Recapping in Classroom Discourse. In N. Pyyry, L. Tainio, K. Juuti, R. Vasquez \& M. Paananen (Eds.) Changing Subjects, Changing Pedagogies: Diversities in School and Education (pp. 132-152).

Tainio, L. \& Grunthal, S. (2016). Language and literature education: principles and reflections on Finnish language and literature. In H. Niemi, A. Toom \& A. Kallioniemi (Eds.) Miracle of 
Education: The principles and practices of teaching and learning in Finnish schools (pp. 145156). $2^{\text {nd }}$ revised edition. Rotterdam: Sense Publishers.

Tainio, L., Karvonen, U. \& Routarinne, S. (2015). Käsitykset oppimateriaalin käytöstä äidinkielen opettajaidentiteetin rakentumisen välineenä. [The use of learning materials in mother tongue and literature education from the point of view of constructing professional identity]. In M. Kauppinen; M. Rautiainen \& M. Tarnanen (Eds.) Rajaton tulevaisuus. Kohti kokonaisvaltaista oppimista [Future without borders - towards integrated learning]. (pp. 189206) Ainedidaktisia tutkimuksia 8. Jyväskylä: Suomen ainedidaktinen tutkimusseura.

Taylor, M.W. (2013). Replacing the 'teacher-proof' curriculum with the 'curriculum-proof teacher: Toward more effective interactions with mathematics textbooks. Journal of Curriculum Studies 45 (3), 295-321.

Thompson, D.R. \& Senk, S.L. (2014). The same geometry textbook does not mean the same classroom enactment. ZDM Mathematics Education 46, 781-765.

TIMSS 2011=Trends in International Mathematics and Science Study. Retrieved 1.9.2016 from http://timssandpirls.bc.edu/timss2011/downloads/T11_IR_Mathematics_FullBook.pdf

Valencia, S.W., Place, N.A., Martin, S.D \& Grossman, P.L. (2006). Curriculum Materials for Elementary Reading: Shackles and Scaffold for Four Beginning Teachers. The Elementary School Journal 107 (1), 93-120.

Waring, H.Z., Creider, C.C., \& Box, C.D. (2013). Explaining vocabulary in the second language classroom: A conversation analytic account. Learning, Culture and Social Interaction 2 (4), 249-264.

Wells, C.G. (1999). Dialogic Inquiry: Towards a Sociocultural Practice and Theory of Education. New York: Cambridge University Press. 
Verloop, N., van Drier, J. \& Meijer, P. (2001). Teacher knowledge and the knowledge base for teaching. International Journal of Educational Research 35, 441-461.

VISK = Auli Hakulinen, Maria Vilkuna, Riitta Korhonen, Vesa Koivisto, Tarja Riitta Heinonen \& Irja Alho 2004: Iso Suomen kielioppi [A Large Finnish Grammar] Helsinki: Suomalaisen Kirjallisuuden Seura [Finnish Literature Society].

APPENDIX. Transcription symbols

./, /? Falling / level / rising intonation

$\uparrow / \downarrow \quad$ Change in pitch height: higher or lower than preceding speech

talk Marked stress (

£talk£ Smiling voice

[talk ] Overlap

(. ) Micropause

(1.4) Pause or gap; duration measured to the nearest tenth of a second and placed in parentheses

talk=talk Latching of turns

$>$ talk $<$ Faster tempo

$<$ talk $>$ Slower tempo

e : : i Sound stretch

${ }^{\circ}$ talk ${ }^{\circ}$ Decreased volume

si- $\quad$ Cut-off

(talk) A guess of what might be said if unclear

(--) A stretch of talk that is unintelligible to the analyst

((coughs)) Verbal description of actions; researcher comments

"talk" A word or an utterance is read aloud from the textbook or workbook

Beginning of embodied actions is marked with a symbol (e.g. *) and temporally located within the course of talk and multimodal activities.

Participant doing the embodied action as well as the type of action is identified in the margin. Sometimes there are several lines for different embodied actions done by one participant at the 
same time.

G Gaze direction (endures until the next shift is marked).

Ha Hand movement (e.g., pointing, putting one's hand up or down)

He Head movement (e.g., nodding)

Mo Motion (e.g., walking)

Actions preparation (e.g., shifting the gaze)

$\rightarrow \quad$ Action described continues until the next symbol 